\title{
Endoscopic submucosal injection of adipose-derived mesenchymal stem cells ameliorates TNBS-induced colitis in rats and prevents stenosis
}

Eduardo Martín Arranz ${ }^{1 *}$, María Dolores Martín Arranz , Tomás Robredo², Pablo Mancheño-Corvo ${ }^{3}$, Ramón Menta ${ }^{3}$, Francisco Javier Alves ${ }^{4}$, Jose Manuel Suárez de Parga ${ }^{1}$, Pedro Mora Sanz ${ }^{1}$, Olga de la Rosa ${ }^{3}$, Dirk Büscher ${ }^{5}$, Eleuterio Lombardo ${ }^{3 \dagger}$ and Fernando de Miguel $^{2 \dagger}$

\begin{abstract}
Background: Mesenchymal stem cells have potential applications in inflammatory bowel disease due to their immunomodulatory properties. Our aim was to evaluate the feasibility, safety and efficacy of endoscopic administration of adipose-derived mesenchymal stem cells (ASCS) in a colitis model in rats.

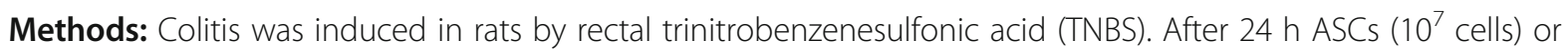
saline vehicle were endoscopically injected into the distal colon. Rats were followed for 11 days. Daily weight, endoscopic score at days 1 and 11, macroscopic appearance at necropsy, colon length and mRNA expression of Foxp3 and IL-10 in mesenteric lymph nodes (MLN) were analyzed.

Results: Endoscopic injection was successful in all the animals. No significant adverse events or mortality due to the procedure occurred. Weight evolution was significantly better in the ASC group, recovering initial weight by day $11(-0.8 \% \pm 10.1 \%$, mean $\pm S D)$, whereas the vehicle group remained in weight loss $(-6.7 \% \pm 9.2 \%, p=0.024)$. The endoscopic score improved in the ASC group by $47.1 \% \pm 5.3 \%$ vs. $21.8 \% \pm 6.6 \%$ in the vehicle group $(p<0.01)$. Stenosis was less frequent in the ASC group ( $4.8 \%$ vs. $41.2 \%, p<0.01)$. Colon length significantly recovered in the ASC group versus the vehicle group ( $222.6 \pm 17.3 \mathrm{~mm}$ vs. $193.6 \pm 17.9 \mathrm{~mm}, p<0.001)$. The endoscopic score significantly correlated with weight change, macroscopic necropsy score and colon length. Foxp3 and IL-10 mRNA levels in MLN recovered with ASC treatment.
\end{abstract}

Conclusions: ASC submucosal endoscopic injection is feasible, safe and ameliorates TNBS-induced colitis in rats, especially stenosis.

Keywords: Inflammatory bowel disease, Cell therapy, Mesenchymal stem cells, Endoscopic treatment

\section{Background}

Inflammatory bowel disease (IBD) includes Crohn's disease (CD) and ulcerative colitis (UC); it is characterized by chronic and relapsing inflammation of the intestinal tract. Its pathogenesis is not completely understood, but a

\footnotetext{
* Correspondence: emarranz@salud.madrid.org

Conference presentation: this work was partially presented at UEGW 2013 in

Berlin and IFATS 2013 11th conference in New York.

${ }^{\dagger}$ Equal contributors

${ }^{1}$ Gastroenterology Department, La Paz University Hospital, Paseo de la

Castellana 261 4th floor, 28046 Madrid, Spain

Full list of author information is available at the end of the article
}

dysregulation of the innate and adaptive immune system, genetic influences and environmental factors are suggested to intervene in the development of the disease. With current treatments, there is still a substantial proportion of patients in whom remission cannot be achieved, leaving unmet needs in the treatment of IBD and leading to the emergence of new treatments [1].

Mesenchymal stem cells (MSCs) are cells that can be isolated from several adult tissues, including bone marrow (BM-MSCs) and adipose tissue (ASCs) [2]. Adult MSCs have been proposed as a potential treatment for 
several diseases, including immune-based treatments, due to their multilineage differentiation capabilities that could allow MSCs to repair damaged tissues [1,3] and their capacity to modulate the function of the majority of immune cells [2, 4]. This treatment could promote the regulation of the inflammatory cascade by inducing tolerogenic phenotypes in antigen-presenting cells (APCs) [5] while inhibiting the proliferation of cytotoxic T-cells and promoting differentiation toward regulatory phenotypes in lymphocytes (regulatory $\mathrm{T}$ cells) and macrophages (M2 macrophages) [6]. The immunomodulatory properties of MSCs rely not only on cell-to-cell interactions but also on effects mediated by a variety of soluble factors [7-9].

MSCs are considered to have low immunogenicity due to a low expression of major histocompatibility complex (MHC)-I and an absence of MHC-II and classic costimulatory molecules, allowing allogeneic use in the clinical setting or even xenogeneic use for research purposes [10, 11].

Regarding IBD cell therapy, MSCs from different sources have reported efficacy through various routes of administration (systemic and local) in animal studies on experimental colitis [12]. Thus, MSC treatment reduced the clinical and histopathological severity in experimental animal models of colitis by downregulating the Th1 and Th17-driven inflammatory response (i.e. reduction of pro-inflammatory cytokines such as tumor necrosis factor (TNF), interferon gamma (IFN $\gamma$ ), interleukin (IL)-6, IL-12 or IL-17), increasing the levels of anti-inflammatory cytokines such as IL-10, and promoting the generation of immune cells with immunomodulatory properties such as FoxP3 regulatory $\mathrm{T}$ cells, regulatory $\mathrm{B}$ cells, and $\mathrm{M} 2$ macrophages [13-18]. The engraftment of MSCs on the inflamed gut might play an important role for their therapeutic effect on IBD models [13, 14, 19, 20] Interestingly, preactivation of MSCs with inflammatory mediators such as IFN $\gamma$, IL-1 $\beta$, IL-25 or poly (I:C) increase their therapeutic capacity in vivo by increasing their immunomodulatory properties and capacity to home to the site of inflammation [21-24]. Noteworthy, efficacy on the treatment of experimental colitis has been also obtained using components of MSCs, such as conditioned medium and extracellular vesicles, showing that MSC secreted factors can ameliorate colitis $[25,26]$. Another aspect of interest is that exposure of MSCs to drugs commonly used in the treatment of IBD do not appear to affect MSC function in vitro [27, 28]. Furthermore, MSC-based therapies have been already used in human studies on fistulizing [29-31] and luminal CD [32-34]. Importantly, Panés et al., recently reported for the first time the significant efficacy of the intralesional treatment with allogeneic ASCs (Cx601) of complex perianal fistulas in Crohn's patients, in a randomized, placebo-controlled phase III clinical trial [35].
Although promising, MSC therapy for IBD still raises some questions, such as the best route of administration to optimize bioavailability in the damaged areas. Conflicting results have been reported to date in terms of intravenous efficacy, and local approaches used in animal experiments, such as intraperitoneal inoculation or colon injection through laparotomy, are impractical for human use [36]. In this study, we propose a new administration route for IBD cell therapy: injecting cells into the colon submucosa using endoscopy, allowing direct cell delivery to the damaged area, while enabling the evaluation of disease severity and evolution.

The aim of this study was to evaluate the feasibility, safety and efficacy of submucosal endoscopic injection of human ASCs in a 2,4,6-trinitrobenzenesulfonic acid (TNBS)-induced colitis model in rats, and the utility of endoscopy to evaluate and follow the course and severity of the disease over time.

\section{Methods \\ Ethics}

All the animal experiments were performed following approval from the Animal Experimental and Welfare Ethics Committee of La Paz University Hospital (CEBA 24-2010), and in accordance with the guidelines of the directive 2010/63/EU from the European Parliament and of the Council on the protection of animals used for scientific purposes and the corresponding Spanish regulations (RD53/2013).

\section{Animals}

Immunocompetent SD-OFA male rats (Charles River, Barcelona, Spain), weighing 375-400 g were used, and were kept in standard stabulation conditions (12 h light/ dark daily cycle) in our facilities with pellet chow and water ad libitum throughout the experiment.

\section{ASC isolation}

For ASC isolation, lipoaspirates were obtained from human adipose tissue after informed consent from otherwise healthy adult male and female donors undergoing cosmetic surgery.

The ASC isolation was performed as previously reported [37]. Briefly, the lipoaspirates were washed twice with phosphate-buffered saline (PBS) to remove contaminating debris and red blood cells and digested at $37{ }^{\circ} \mathrm{C}$ for $30 \mathrm{~min}$ with $0.075 \%$ collagenase (Type I, Invitrogen, Carlsbad, CA, USA) in the PBS. The digested sample was washed with $10 \%$ fetal bovine serum (FBS), treated with $160 \mathrm{mM}$ ammonium chloride to eliminate the remaining red blood cells, suspended in culture medium (Dulbecco's modified Eagle medium), containing 10\% FBS, and filtered. The cells were seeded onto tissue culture flasks and expanded at $37{ }^{\circ} \mathrm{C}$ and $5 \%$ carbon 
dioxide. The culture medium was changed every 3 to 4 days. The cells were passed to a new culture flask when the cultures reached of confluence, and were phenotypically characterized according to their capacity to differentiate into chondro-, osteo-, and adipogenic lineages $[38,39]$. In addition, ASCs were verified by flow cytometry staining for specific surface markers: positive for HLA-I, CD73, CD90 and CD105; and negative for HLAII, CD14, CD19, CD34 and CD45. A pool of six various ASC samples from male and female donors (population doubling 12-14) were used in the study.

\section{Experimental design}

On day 0 , the rats were weighed and colitis was induced. On day 1 , the animals that presented weight loss underwent endoscopic evaluation under anesthesia. After colonoscopy, treatment was subsequently applied according to the assigned experimental group: ASC group $(n=25)$, or vehicle (PBS, $n=21$ ). Two additional groups were used: one without colitis induction was used as a healthy control $(n=25)$; and another with induced colitis but without endoscopy or treatment, the TNBS group $(n=13)$, was used as a safety control for the endoscopy and injection.

All the animals were weighed daily. On day 11, a second colonoscopy was performed under anesthesia for the assessment of colonic damage; blood was then obtained by cardiac puncture, and the animals were euthanized with saturated potassium chloride through intracardiac injection. A medial abdominal incision was then performed for macroscopic evaluation.

\section{Colitis induction}

On day 0 , the animals were weighed and anesthetized with inhaled isofluorane (5\% induction and $2 \%$ maintenance), and feces were removed by gentle manual pressure of the abdomen. While in a supine position, a flexible plastic intravenous catheter (BD Insyte ${ }^{\mathrm{tw}}$ Autoguard $^{\mathrm{mw}} 18 \mathrm{G}$, Becton Dickinson, Madrid, Spain) was inserted $5 \mathrm{~cm}$ from the anal verge, and a single bolus of $0.5 \mathrm{ml}$ of TNBS
(Sigma-Aldrich, Tres Cantos, Spain), $30 \mathrm{mg} / \mathrm{ml}$ diluted in $50 \%$ ethanol, freshly prepared, was delivered slowly. The rats were kept in a head-down position for $1 \mathrm{~min}$ to prevent immediate expulsion of TNBS, and were then returned to their cages where they recovered consciousness shortly thereafter $[40,41]$.

\section{Endoscopy}

Approximately $24 \mathrm{~h}$ after colitis induction, the animals were weighed and anesthetized with inhaled isofluorane. Prior to the endoscopy, colon cleansing was performed with a 20-ml room temperature (RT) saline solution enema.

The endoscopy was performed with a videoendoscope GIF-XP-160 (Olympus Optical Co Ltd, Tokyo, Japan), with an outer diameter of $5.9 \mathrm{~mm}, 180^{\circ} / 90^{\circ}$ up/down bending, $100^{\circ} / 100^{\circ}$ right $/$ left bending, $103 \mathrm{~cm}$ working length, $120^{\circ}$ view field, $2 \mathrm{~mm}$ working channel and a CV-145 processor (Olympus Optical Co Ltd).

While in the supine position, the endoscope was inserted into the rectum, advancing until the splenic flexure $(8-10 \mathrm{~cm})$. All the endoscopies were digitally recorded for posterior analysis by two different observers.

To assess colitis severity, we developed an endoscopic index, adapted from published animal endoscopic experiments $[19,42-45]$ and human IBD scales [46-48]. The degree of inflammation, ulceration, stenosis, thickening, bleeding and extent of disease were scored individually and a final score was obtained by adding all the variables, ranging from 0 to 25 (Table 1 ).

\section{Cell injection}

Endoscopic needles (23G $\times 5 \mathrm{~mm}, 160 \mathrm{~cm}$ length, Olympus Optical Co Ltd) were used for submucosal injection. Following endoscopic evaluation, a needle was passed through the endoscope's working channel, then introduced tangentially into the submucosa using the dynamic endoscopic submucosal injection method [49], injecting $0.2 \mathrm{ml}$ PBS containing ASCs or not (total dose

Table 1 Endoscopic score. The score is the result of the sum of each item

\begin{tabular}{|c|c|c|c|c|c|}
\hline Inflammation & Ulceration type & Stenosis & $\begin{array}{l}\text { Colon } \\
\text { thickening }\end{array}$ & $\begin{array}{l}\text { Spontaneous } \\
\text { bleeding }\end{array}$ & $\begin{array}{l}\text { Inflammation } \\
\text { longitudinal extent }(\mathrm{cm})\end{array}$ \\
\hline 0 Normal aspect of the mucosa & 0 No ulcers & 0 No stenosis & 0 Transparent & 0 Absent & \\
\hline 1 Hyperemia & 1 Cicatricial ulcer & 1 Mild stenosis & 1 Mild & 1 Present & \\
\hline $\begin{array}{l}2 \text { Ulceration, covering }<1 / 4 \\
\text { of the circumference }\end{array}$ & 2 Superficial ulcer & $\begin{array}{l}2 \text { Stenosis preventing } \\
\text { endoscope pass }\end{array}$ & 2 Pronounced & & \\
\hline $\begin{array}{l}3 \text { Ulceration, covering } 1 / 4 \text { to } 1 / 2 \\
\text { of the circumference }\end{array}$ & 3 Medium depth ulcer & & 3 Totally opaque & & \\
\hline $\begin{array}{l}4 \text { Ulceration, covering }>1 / 2 \\
\text { of the circumference }\end{array}$ & 4 Deep ulcer & & & & \\
\hline 5 Circumferential ulceration & 5 Necrotic ulcer & & & & \\
\hline $\begin{array}{l}6 \text { Circumferential ulceration+ } \\
\text { longitudinal extension }\end{array}$ & & & & & \\
\hline
\end{tabular}


$10^{7}$ ASCs) in four different spots surrounding the lesions. This dose and number of injections were chosen taking into account the maximum concentration in which ASC viability was guaranteed and covering the extension of the damaged colon while keeping a low volume of fluid, and thus avoiding potential mucosal damage caused by over injection.

The complete procedure, including submucosal injections, usually took no longer than $10 \mathrm{~min}$.

\section{Macroscopic evaluation}

After euthanasia, the abdominal cavity was exposed through medial abdominal incision, allowing visualization of the colon and the presence of adherences. Photographs were taken for evaluation by two different observers. Macroscopic damage was assessed by the degree of colon wall vascularization, wall thickening and presence of adherences, for a final score ranging from 0 to 9 (Table 2).

The colon was removed to measure its entire length from the colocecal junction to the anal verge, and the distal part excised and fixed in buffered formalin.

Mesenteric lymph nodes (MLN) were collected, snapfrozen in liquid nitrogen and stored at $-80{ }^{\circ} \mathrm{C}$ for further use.

\section{Immunohistochemistry}

Distal colonic tissue was fixed in 10\% buffered formalin, embedded in paraffin, cut into $5-\mu \mathrm{m}$ sections and stained with hematoxylin-eosin.

To detect ASCs by immunohistochemistry, tissue sections were dewaxed and rehydrated, and then microwaved for $20 \mathrm{~min}$ in $0.01 \mathrm{M}$ trisodium citrate buffer $\mathrm{pH}$ 6.0. After cooling to RT, endogenous peroxidase was blocked by incubating the tissues for $10 \mathrm{~min}$ in $1 \% \mathrm{H}_{2} \mathrm{O}_{2}$ in methanol. After rinsing with TBST buffer, the samples were blocked for $1 \mathrm{~h}$ at RT with $5 \%$ normal goat serum and $1 \%$ bovine serum albumin in TBST, then incubated overnight at $4{ }^{\circ} \mathrm{C}$ with anti-human mitochondria antibody (113-1, Abcam, Cambridge, UK), 1:500 in blocking solution. Detection was performed with goat anti-mouse biotinylated IgG (Life Technologies, Carlsbad, CA, USA)

Table 2 Macroscopic damage score. The score is the result of the sum of each item

\begin{tabular}{lll}
\hline Colon wall vascularization & $\begin{array}{l}\text { Colon wall } \\
\text { thickening }\end{array}$ & $\begin{array}{l}\text { Adherences to } \\
\text { the colon wall }\end{array}$ \\
\hline 0 Normal & 0 Normal & 0 Absence \\
$\begin{array}{l}1 \text { Mild vascular pattern } \\
\text { distortion }\end{array}$ & 1 Mild & 1 Mild adherences \\
$\begin{array}{l}2 \text { Pronounced vascular } \\
\text { pattern distortion }\end{array}$ & 2 Pronounced & 2 Moderate adherences \\
$\begin{array}{l}3 \text { Complete absence } \\
\text { of vascular pattern }\end{array}$ & 3 Very intense & 3 Pronounced adherences \\
\hline
\end{tabular}

1:250 in blocking solution for $1 \mathrm{~h}$ at RT, followed by the ABC kit (HRP-based, Vector Laboratories, Burlingame, $\mathrm{CA}$, USA), for $1 \mathrm{~h}$ at RT, and DAB as the chromogen. Sections were counterstained with hematoxylin, and mounted with DPX.

\section{RNA isolation, reverse transcription-polymerase chain reaction (RT-PCR), quantitative PCR}

Total RNA was isolated from frozen MLN with TRIzol reagent (Ambion, Life Technologies), according to the manufacturer's recommendations. The average yield was $1.91 \pm 0.06 \mu \mathrm{g}$ RNA per mg MLN. Complementary DNA synthesis was performed with MultiScribe Reverse Transcriptase and oligo $(\mathrm{dT})_{16}$ (Applied Biosystems, Foster City, CA, USA), according to the manufacturer's recommendations. Standard PCR was performed with $1 \mathrm{u}$ DNA polymerase (Biotools, Madrid, Spain) and $0.5 \mu \mathrm{M}$ each oligonucleotide for 35 cycles of $30 \mathrm{~s}$ at $95{ }^{\circ} \mathrm{C}, 30 \mathrm{~s}$ at $60{ }^{\circ} \mathrm{C}$ and $30 \mathrm{~s}$ at $72{ }^{\circ} \mathrm{C}$. The sequences of the oligonucleotides were as follows: Foxp3, forward, 5'-CAG CTG CCT ACA GTG CCC CTA G-3', reverse, 5'-CGT TTG CCA GCA GTG GGT AG-3'; IL-10, forward, 5'-GGA TCC AAC GCA GCC TTG CAG AAA C-3', reverse, 5'-ACG CGT ATT TTT CAT TTT GAG TGT CAC GTA GGC -3'; ß-Actin, forward, 5'-AGA GGG AAA TCG TGC GTG-3', reverse, 5'-CTG GGT ACA TGG TGG TGC-3'. The PCR products were analyzed on 1. $6 \%$ agarose gels in $0.5 \times$ TBE buffer (Tris-Borate-EDTA) containing $1 \times$ REALSafe (Durviz, Valencia, Spain) and with a digital photodocumentation system (Alliance 2.7, UVitec, Cambridge, UK).

For the quantitative PCR, we used a CFX96 Touch system (Bio-Rad, Hercules, CA, USA) and Quantimix Easy kit (Biotools, Madrid, Spain) containing $0.3 \mu \mathrm{M}$ each oligonucleotide and $0.5 \times$ SYBR Green (Life Technologies), for 40 cycles of $20 \mathrm{~s}$ at $95{ }^{\circ} \mathrm{C}, 20 \mathrm{~s}$ at $60{ }^{\circ} \mathrm{C}, 30$ $\mathrm{s}$ at $72{ }^{\circ} \mathrm{C}$ and $2 \mathrm{~s}$ at $80{ }^{\circ} \mathrm{C}$ (when fluorescence was acquired). The oligonucleotide sequences were as follows: Foxp3, forward, 5'-TGG CAG GGA AGG AGT GTC AG-3', reverse, 5'-GGC TGA CTT CCA AGT CTC GT3'; IL-10, forward, 5'-GGC TCA GCA CTG CTA TGT TGC C-3', reverse, 5'-AGC ATG TGG GTC TGG CTG ACT G-3'; GAPDH, forward, 5' - CGT GGA GTC TAC TGG TGT CTT CAC C-3', reverse, 5'- GAT GGC ATG GAC TGT GGT CAT GAG C-3'. We used the standard $2^{-\Delta \Delta C t}$ method to quantitate expression levels.

\section{Statistics}

The statistical analyses were performed with SPSS 20.0 (SPSS Inc., Chicago, IL, USA) and Prism 5.01 (GraphPad Software Inc., San Diego, CA, USA). The statistical level of significance was $p<0.05$, corrected for multiple comparisons where appropriate.

The quantitative data are expressed as mean \pm SD . 
The differences between continuous and qualitative variables were calculated with non-parametric tests: the Kruskal-Wallis or the Mann-Whitney $U$ test. The Wilcoxon signed-rank test was used for paired analysis.

For the frequency analysis between qualitative variables we used the chi-squared test or Fisher's exact test, when necessary (if $n<20$ or any value in the expected value table was $<5$ ).

Correlations were analyzed by Pearson's correlation coefficient. Slopes of linear regression were compared with the beta coefficient of the simple linear regression and its standard error.

Survival curves were made using the Kaplan-Meier method and the log-rank test.

\section{Results}

\section{Basal characteristics}

Twenty-four hours after a TNBS enema, the rats suffered significant weight loss $(-3.9 \% \pm 2.4 \%$ vs. $1.0 \% \pm 1$. $4 \%$ in the control group, $p<0.001)$; diarrhea and other signs of discomfort were also evident in the colitic animals. The endoscopic score increased significantly in these animals compared with the control group (16.1 \pm 4.9 vs. $1.3 \pm 1.9, p<0.001)$. The selection of rats to either treatment group, PBS or ASC, was not biased, given neither weight loss $(-3.6 \% \pm 2.8 \%$ vs. $-3.0 \% \pm 1.9 \%$, respectively, $p=0.21)$ nor endoscopic score (17.6 $\pm 4.3 \mathrm{vs}$. $15.0 \pm 5.0$, respectively, $p=0.08$ ) was statistically different.

\section{Feasibility and safety}

The endoscopic injection was successful in all the rats, with formation of a visible submucosal bleb (Fig. 1a-c). Neither significant adverse events nor mortality due to the procedure occurred.

We assessed the correct location of the cell injection using immunohistochemistry with anti-human mitochondria antibody, which allows detection of human ASCs. In a healthy animal in which ASCs were injected following the same method of the experiment, a dense accumulation of positive cells was observed in the colon submucosa $24 \mathrm{~h}$ after the injection, with no signs of immune reaction (Fig. 1d).

In the colitic rats, we also detected ASCs in the colon submucosa $24 \mathrm{~h}$ after cell injection, with intense inflammatory infiltrate and edema (Fig. 1e). At the end of the experiment, however, we could not detect ASCs by immunohistochemistry within the submucosa, even in the animals that showed signs of improvement: the extensive areas that were seen in the submucosa of these animals showed cells with a fibroblastic phenotype, less inflammatory infiltrate and almost absent edema (Fig. 1f).

There was no difference in overall survival rate with either treatment, (85.7\% PBS vs. $83.3 \%$ ASCs vs. $84.6 \%$ TNBS, $p$ is not significant). As expected, the healthy control group suffered no deaths (data not shown).

\section{Weight evolution}

All the control rats gained weight steadily throughout the course of the experiment, reaching a significant

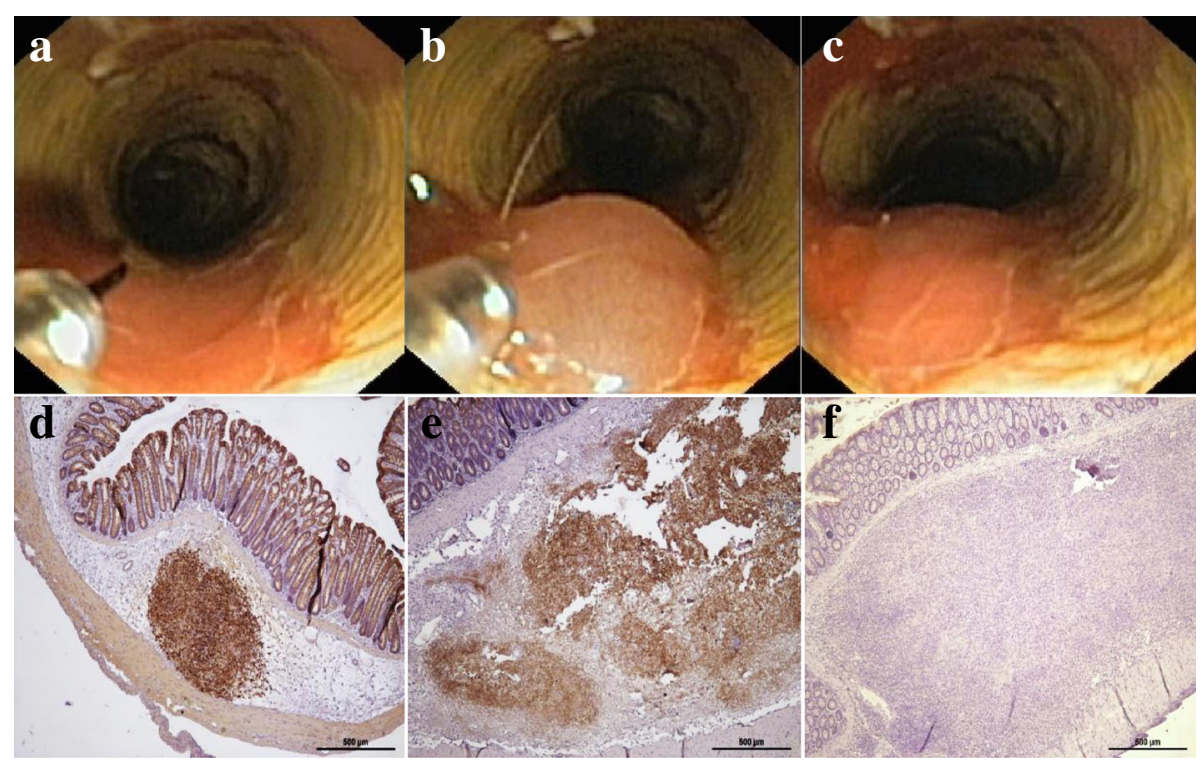

Fig. 1 Injection feasibility and cell location. Cells were injected into the submucosa using a 23G endoscopic needle. a, b and $\mathbf{c}$ injection procedure, bleb formation and endoscopic appearance after injection. Cells are injected into the submucosa, this is demonstrated by presence of hASC staining (brown) using anti-human mitochondria antibodies in colon submucosa $24 \mathrm{~h}$ after injection in a healthy animal (d) or in a colitic animal (e). Eleven days after injection in a colitic animal that recovered weight cells no staining was seen (f) 
increase of $9.9 \% \pm 3.4 \%(p<0.001)$ compared with their initial weight (Fig. 2a, b). Regarding the colitic rats, the TNBS group suffered rapid weight loss, reaching $-11.9 \% \pm 2.1 \%$ at day 3 ; they then began a slight recovery, with mean weight loss at the end of the experiment of $-8.7 \% \pm 8.2 \%(p=0.021)$ (Fig. 2a). The PBS-treated rats also exhibited a similar pattern, with significant weight loss that reached a maximum on the fifth day after induction with the hapten $(-11.3 \% \pm 4.2 \%)$. After this day, the rats gained weight slightly, and, on average, did not reach initial values $(-6.7 \% \pm 9.2 \%$ on day 11 , $p=0.024$ ) (Fig. 2a).

The ASC-treated rats also suffered an initial weight loss that reached its peak on day $3(-8.4 \% \pm 4.2 \%)$, after which, unlike the other colitic groups, weight recovery was evident, reaching, on average, initial values by the end of the experiment $(-0.8 \% \pm 10.1 \%$ on day $11, p=0$. 741) (Fig. 2a). In fact, the ASC-treated animals gained weight with a slope comparable to the one observed in the control group $(0.93 \pm 0.08$ vs. $0.89 \pm 0.04$, respectively, $p=0.601$ ), whereas the slopes for the TNBS and the PBStreated groups were significantly flatter $(0.52 \pm 0.09, p=0$. 001 , and $0.41 \pm 0.09, p<0.001$, respectively) (Fig. 2a).

Weight recovery was statistically significant in the ASCs group over the PBS group on day $5(-6.5 \% \pm 5$. $86 \%$ vs. $-11.32 \% \pm 4.18 \%$, respectively, $p=0.009)$, day 9 $(-3.7 \% \pm 9.1 \%$ vs. $-8.5 \% \pm 6.8 \%$, respectively, $p=0.034)$,

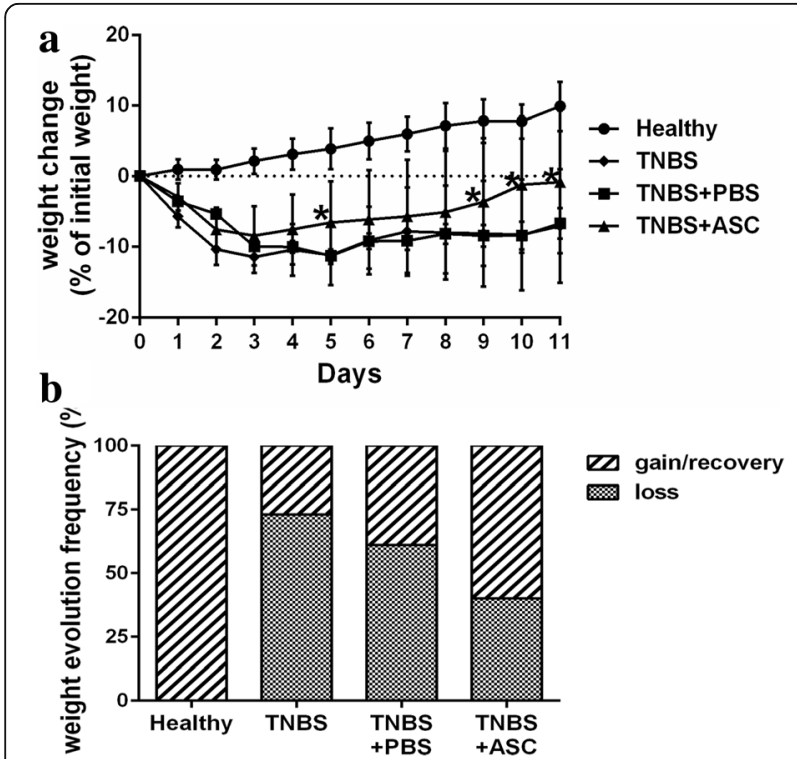

Fig. 2 hASC improves weight evolution. Colitis induces weight loss. a Body weight was measured daily. Faster improvement was seen in ASC group, being significantly different on days 5, 9, 10 and $11 .{ }^{*} p<0.05$. b Frequency of weight recovery by treatment group. $60 \%$ of animals treated with ASC recovered weight vs. $38.9 \%$ in PBS group and 27.3\% in TNBS group ( $p=n$.S.). ASCs adipose-derived mesenchymal stem cells, PBS phosphate-buffered saline, TNBS trinitrobenzenesulfonic acid day $10(-1.9 \% \pm 9.4 \%$ vs. $-8.4 \% \pm 8.6 \%$, respectively, $p=0.013)$ and day $11(-0.8 \% \pm 10.1 \%$ vs. $-6.7 \% \pm 9.2 \%$, respectively, $p=0.037$ ).

Individually, some animals from every colitic group recovered initial weight by the end of the experiment, but the frequency of weight recovery was higher in the ASCtreated animals compared with the TNBS and PBS groups: $60.0 \%(12 / 20), 27.3 \%(3 / 11)$ and $38.9 \%$ (7/18), respectively ( $p$ is not significant) (Fig. $2 \mathrm{~b}$ ).

\section{Endoscopic analysis}

After colitis induction, endoscopic signs of damage were evident, with disappearance of vascular pattern, edema and ulceration (Fig. 3a, b), which improved over time, in particular in the ASC group (Fig. 3d).

We evaluated the endoscopic mucosal damage following the score described in Table 1, with higher scores for more severe inflammation.

There is no validated score for endoscopic evaluation of experimental colitis severity. The most commonly used variable for follow-up is daily weight; therefore, we first analyzed the overall correlation between our colonoscopy score and weight change, finding a strong correlation at both time points evaluated: at day 1, the Pearson coefficient was $r=-0.75(p<0.001)$ and at the end of the experiment at day $11 r=-0.78(p<0.001)$ (Additional file 1: Figure S1).

At day 11, the final endoscopic score was $9.1 \pm 5.6$ in the ASC group compared with $13.3 \pm 6.2$ in the PBS group ( $p=0.052$ ) (Fig. 3e). As expected in an acute colitis model, both groups improved; however, this improvement was significantly greater in the ASC group compared with the PBS group $(-6.6 \pm 2.9$ vs. $-3.5 \pm 5$ points, respectively, $p=0.011$ ). This represents a mean improvement of $47.1 \% \pm 5.3 \%$ in the ASCs compared with $21.8 \% \pm 6.6 \%$ in the PBS group $(p=0.005)$.

ASC treatment dramatically decreased the development of stenosis (defined as the presence of a narrowing of the lumen that hinders or prevents passage of the endoscope) when evaluated by endoscopy on day 11 (Fig. 4a, b). While in the PBS group, 7 of 17 evaluable rats $(41.2 \%)$ developed stenosis, whereas only 1 of 21 rats $(4.8 \%)$ did so in the ASC group $(p=0.001)$ (Fig. $4 \mathrm{c}$ ).

\section{Macroscopic evaluation}

Macroscopic evaluation of the abdominal cavity was performed after euthanasia at day 11. Vascular pattern distortion, colon wall thickening and fat tissue or visceral adhesions to the colon were assessed (Fig. 5a-d). Both the TNBS and PBS groups showed a significantly higher macroscopic damage score compared with the control group $(6.5 \pm 2.5, p<0.001 ; 6.1 \pm 2.7, p<0.01 ; 2.2 \pm 1.0$, respectively). This total score and all the evaluated subitems were lower in the ASC group than in the PBS and 


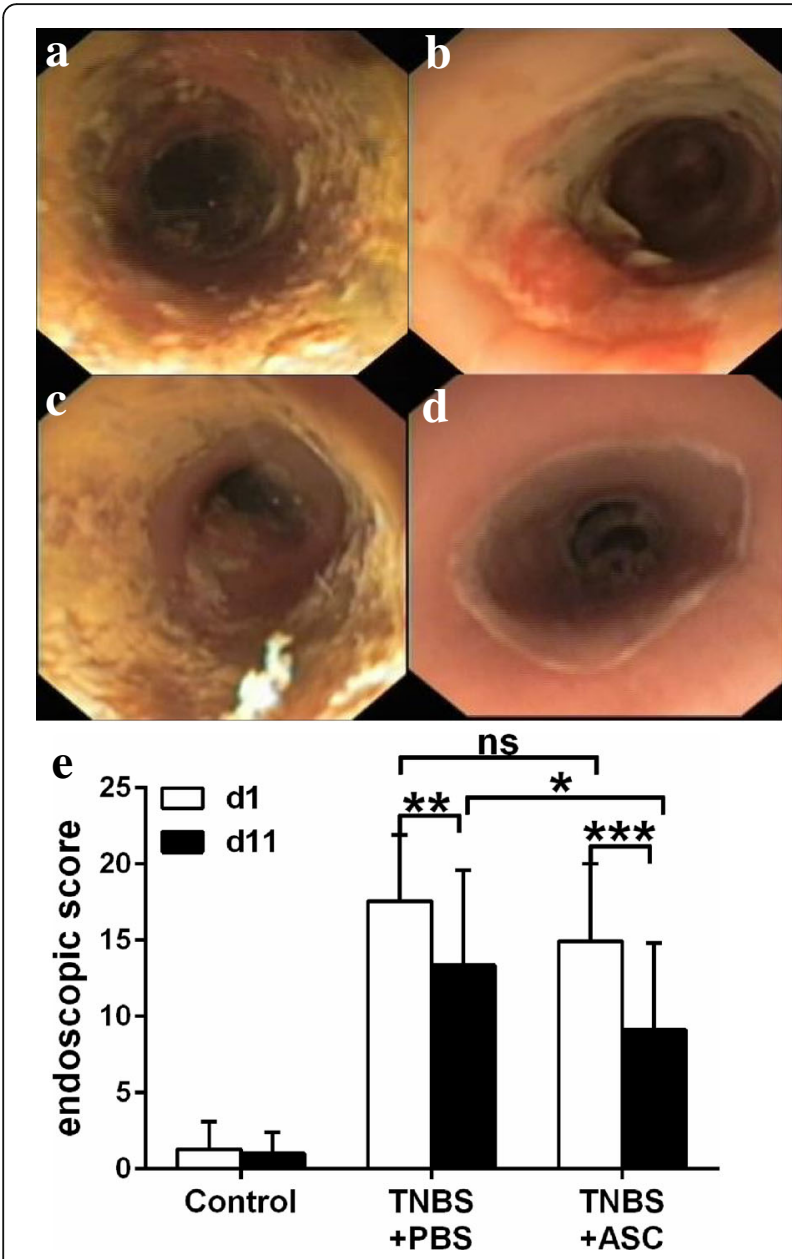

Fig. 3 Endoscopic evaluation of the colitis. TNBS induced distal colitis characterized by erythema, edema, loss of vascular pattern and ulceration. This is still evident after 11 days of the onset of the disease. $\mathbf{a}-\mathbf{b}$ Endoscopic evolution of a PBS-treated rat at day 1 and 11. c-d Endoscopic evolution of an ASC-treated rat at day 1 and 11 . e Evolution of the endoscopic score over time per treatment group. The endoscopic score at baseline was not different between groups. As expected this score improved between day 1 and 11 in both groups. The change in ASC group was greater than in the PBS group $(-6.6 \pm 2.9$ vs. $-3.5 \pm 5$ points, $p=0.011)$. Score at day 11 did not achieve significant difference between groups $p=0.052 .{ }^{* *} p<0.01$, ${ }^{* * *} p<0.001$. ASCs adipose-derived mesenchymal stem cells, PBS phosphate-buffered saline, TNBS trinitrobenzenesulfonic acid

TNBS groups, although there was no statistical significance among them. Nevertheless, the macroscopic damage score in the ASC group $(4.7 \pm 2.5)$ decreased to values not statistically different from the control group (Fig. 5e).

The macroscopic damage score correlated significantly with weight change on the day of euthanasia, with a Pearson correlation $r=0.78(p<0.001)$, and with the endoscopic index on the same day (Pearson correlation $r=0.80, p<0.001$ ) (Additional file 2: Figure S2).

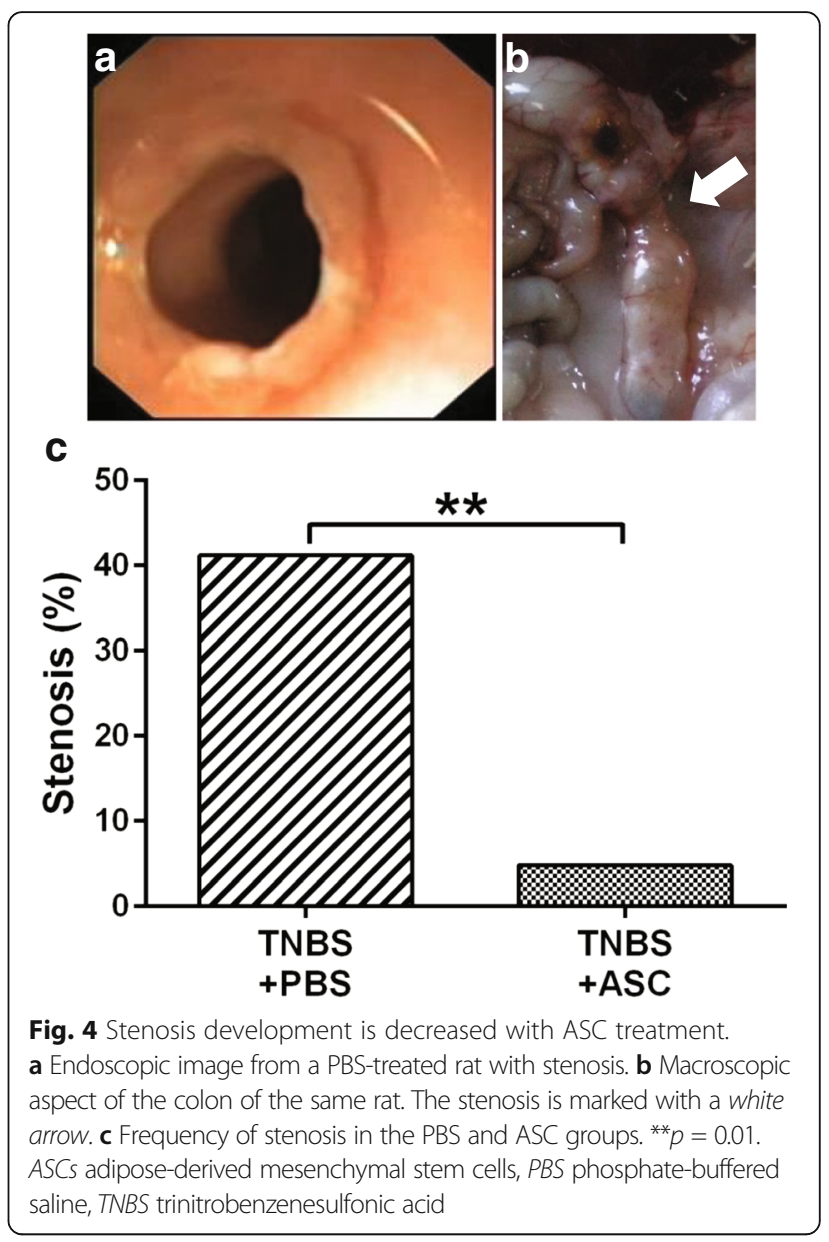

Colitis is known to induce a marked shortening of the colon. In the TNBS group and the PBS group, colon length was shorter than in the control group (204.5 \pm $24.6 \mathrm{~mm}, p<0.001 ; 193.6 \pm 17.9 \mathrm{~mm}, p<0.001$, vs. $237.2 \pm 16.3 \mathrm{~mm}$, respectively). This shortening was significantly improved in the ASC group, with a mean length of $222.6 \pm 17.3 \mathrm{~mm}$, showing no difference from the control group $(p=0.2)$ and statistically longer than the PBS group ( $p<0.001)$ (Fig. 5f). Colon length also correlated significantly with the endoscopic score at the end of the experiment, with a Pearson correlation $r=-0.33$, $p=0.041$ (Additional file 3: Figure S3). Distal colonic samples stained with hematoxylin-eosin were evaluated for ulceration and histologic recovery (Fig. 6).

\section{Immunomodulatory effects mediated by ASCs}

The possible immunomodulatory effect of the local injection of ASCs into the colon submucosa was evaluated at day 11 in mesenteric lymph nodes by measuring the mRNA expression of Foxp3, a transcription factor expressed by regulatory T lymphocytes, and of IL-10, an anti-inflammatory cytokine produced by various cell types. 


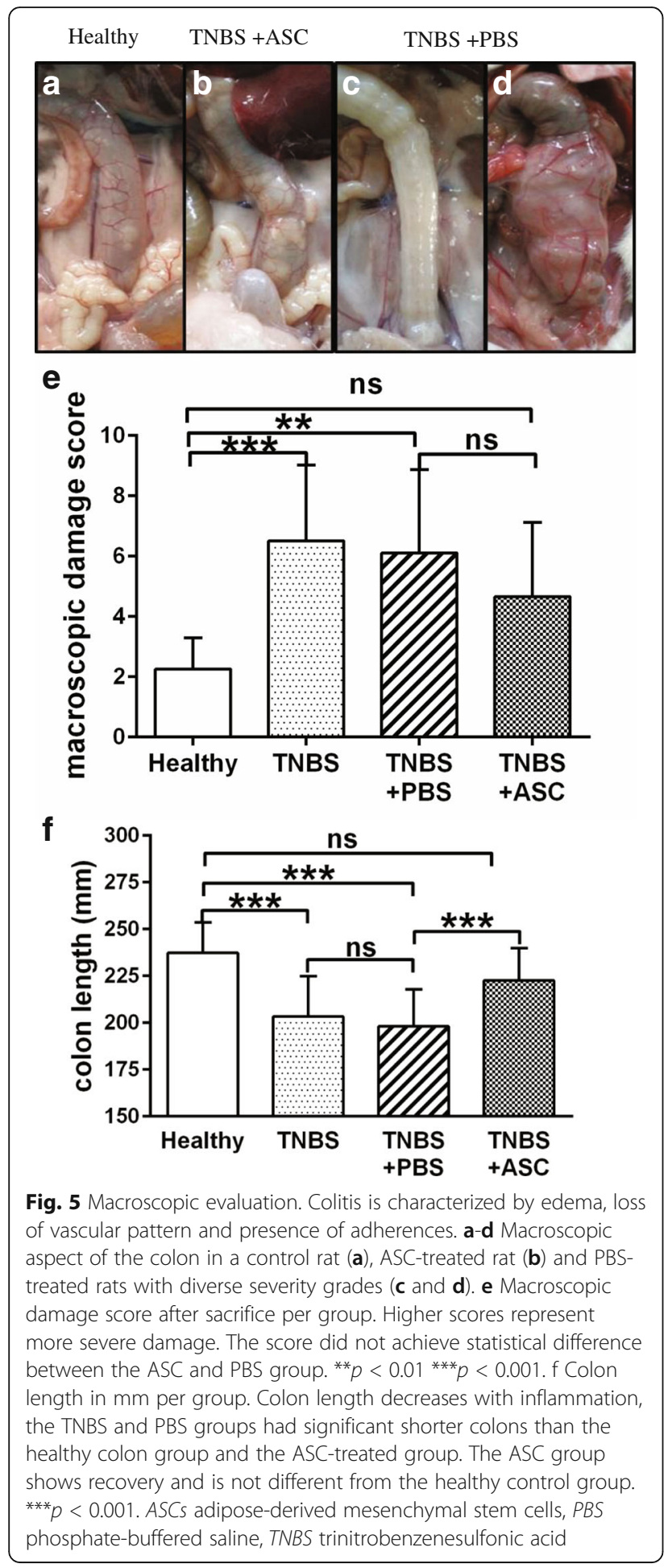

As shown in Fig. 7a, Foxp3 expression decreased dramatically in the untreated colitic rats, being three times smaller in the TNBS group than in the control group ( 0 . $33 \pm 0.1$ vs. $1.05 \pm 0.3$, respectively, $p=0.014)$. The ASC group showed a recovered expression (1.27 \pm 0.5 times),

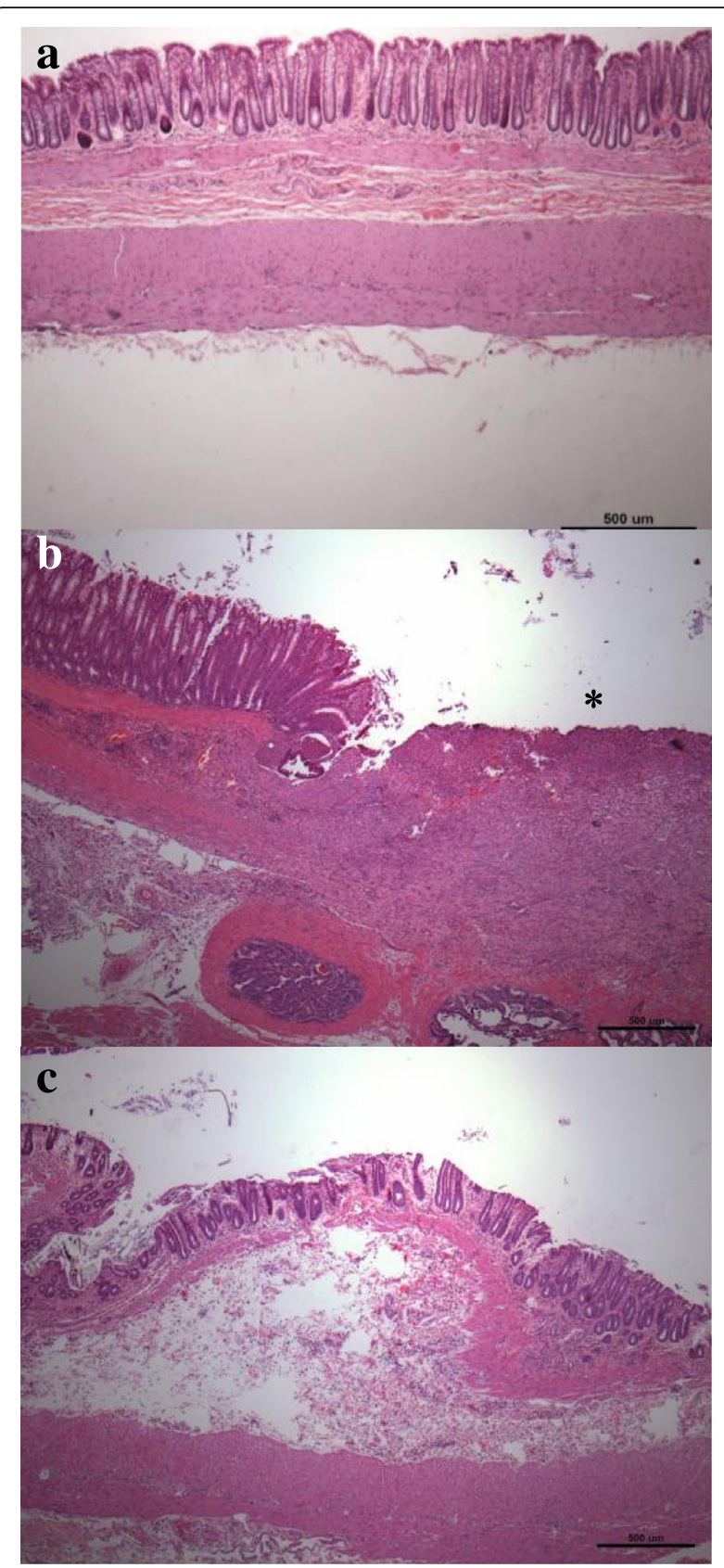

Fig. 6 Histologic evaluation. a Hematoxylin-eosin staining of a control animal. b-c Sections made at the injection point of TNBS colitis at 11 days (b). Animal treated with PBS injection, showing mucosal ulceration * (c) TNBS colitis and ASC injection, showing, slight crypt distortion persists, but no ulcers or active inflammation. Scale bar $500 \mu \mathrm{m}$

which was not statistically different from the control group ( $p=0.46)$ (Fig. 7a).

Regarding IL-10 mRNA, the expression of IL-10 was reduced in the TNBS colitic group (0.56 \pm 0.2 times) compared with the healthy control group $(1.07 \pm 0.4, p=0.05)$, whereas in the ASC-treated animals, IL-10 expression was similar to the control group (1.05 $\pm 0.1, p=0.71)$ (Fig. 7b). 


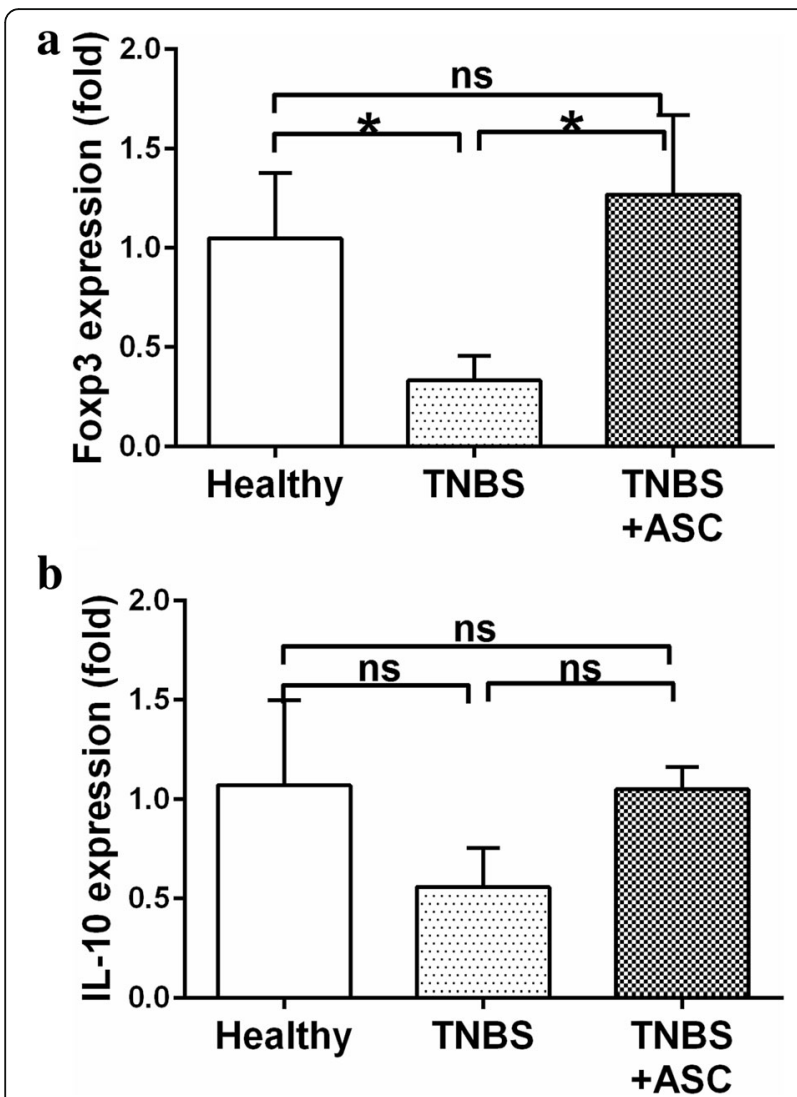

Fig. 7 mRNA expression in MLN.ASC treatment has immunomodulatory effects. Mesenteric lymphatic nodes were isolated and frozen in liquid nitrogen. RNA was isolated and quantitative PCR was made for FoxP3 expression and IL-10. Standard $2-\Delta \Delta \mathrm{Ct}$ method to quantitate expression levels was used $n=4$. a Foxp3 is significantly increased in ASC treated rats $(n=4)$. $\mathbf{b}$ IL-10 expression did not reach significant difference. ${ }^{*} p<0.05$. ASCs adipose-derived mesenchymal stem cells, IL-10, interleukin-10, TNBS trinitrobenzenesulfonic acid

\section{Discussion}

In the present study, we hypothesized that local administration by endoscopy of ASCs in the submucosa of colitic rats could be an optimal route of administration to increase the bioavailability of ASCs in the damaged areas of the colon and reduce the severity of the disease.

Therefore, we evaluated the feasibility, safety and efficacy of endoscopic ASC administration in an experimental colitis model, as well as the utility of endoscopy to follow the course of the disease in rats.

Our results support endoscopy as a useful administration route for ASC treatment for colitis and its utility for assessing treatment efficacy and severity of the disease in an animal model. We also demonstrate that submucosal injection of human ASCs ameliorates the course of TNBS colitis in immunocompetent rats.

IBD pathogenesis is complex and involves multiple mechanisms. One of the most significant is the disbalance between pathogen recognition and tolerance against commensals. In this setting, MSC treatment could help restore this balance due to its diverse immunomodulatory properties, promoting both differentiation of lymphocytes and mononuclear cells toward tolerant phenotypes and suppression of activated lymphocytes [6]. Several studies have tried stem cell therapy in colitic animals with both BM-MSCs and ASCs [13-15, 19, 36, 50-54].

Although promising, MSC therapy has yet to address several questions, such as optimal doses and administration routes, selection of patients and elucidation of mechanisms of action, making animal models essential.

Regarding administration route, it has been demonstrated that ASCs have homing capabilities toward damaged areas [51, 55]. While convenient, intravenous use remains controversial due to concerns about lung entrapment that could lead to a reduced number of available cells and therefore reduced efficacy and potential adverse events $[19,52,54,56]$. Delivering the cells directly into the damaged area would overcome this issue, and intraperitoneal use has been used in animals, but this approach is impractical in humans. Injecting cells through endoscopy could offer advantages in experimental studies and translational potential for future human use.

The TNBS chemical-induced model of colitis is inexpensive, reproducible, easy to handle and widely used [40, 41, 57]. Although human IBD is better represented by knock-out mouse models, we chose the TNBS model because it leads to distal colitis and can be used in rat strains that can grow enough to make endoscopy a feasible tool for evaluation and treatment. Therefore, even if the use of a chemical model is a limitation of our study, it is useful for the evaluation of the endoscopic administration route and that efficacy data obtained with this model is meaningful.

Our data demonstrate that endoscopy in trained hands is a simple and very effective tool for follow-up and evaluation of colitic rats, with an excellent safety profile, given we did not observe any case of perforation or significant bleeding due to the injection, and no deaths were attributed to the procedure. Moreover, there were no significant differences in the evolution of the rats with colitis without endoscopy (TNBS group) and the group with endoscopy and PBS injection. This safety profile is one of the main advantages of the technique, allowing in vivo repeated assessment of the severity and evolution of the disease, and also reducing the number of animals needed.

While it has been used for carcinogenesis [43, 58-63] and colitis [19, 42, 44, 64] evaluation, these studies are heterogeneous in aims, endoscopes and scoring systems. Although lacking a formal validation, the endoscopic score developed for this study showed a significant correlation with body weight changes, macroscopic damage and colon length, which are commonly used variables in 
experimental colitis. Further studies will determine which is the best score for colitis evaluation in murine models.

ASC administration demonstrated improvement in weight recovery, in colon length and in the endoscopic damage score. In addition, the macroscopic damage observed after euthanasia was numerically smaller in the treated group, although it did not reach statistical significance. These are among the main variables commonly used in colitic animals, thus supporting the ameliorating effect of the cells, and confirming the results of previous studies $[13-15,19,36]$. Although these studies differ in protocol, severity of the colitis, animal strains, cell type, dose and administration routes, all suggest a beneficial effect of ASC treatment in murine chemical-induced colitis models.

One of the main results of our study was the decrease in stenosis development; even though the experiment was not designed for this purpose, the difference between the ASC and the vehicle group is remarkable. Whereas in the PBS group stenosis developed in $41 \%$ of the animals, in the ASC group this occurred in $4.8 \%$. This is an observation that, in our opinion, deserves further studies to elucidate whether ASCs are able to prevent stenosis development in other models and if they can also help to reverse established stenosis.

A limitation of our study is the lack of histological scoring; in our hands, microscopic changes in inflammation and healing were inconsistent.

We were able to detect the ASCs in colon submucosa using anti-human mitochondrial antibodies $24 \mathrm{~h}$ after injection, proving the correct location of the cells after the endoscopic administration. In agreement with previous studies reporting a short persistence of the cells in vivo, ASCs were not detected after 11 days. The fate of the ASCs in vivo remains largely unknown to date [65].

In order to determine whether the endoscopic administration of ASCs resulted in immunomodulatory effects in the colitic rats, we determined the levels of the antiinflammatory cytokine IL-10 and the transcription factor Foxp3, characteristic of regulatory $\mathrm{T}$ cells. Our results show that IL-10 and Foxp3 levels in MLN of ASCtreated rats were elevated, supporting the notion that ASCs administered endoscopically have an immunomodulatory mechanism of action, similar to what has been previously described for MSCs using other routes of administration [13-18]. Nevertheless, we did not investigate in detail the mechanisms underlying the efficacy of ASCs and, therefore, further studies are needed to better understand the mechanism of action of ASCs administered through the endoscopic route of administration.

We cannot completely rule out a potential immunogenicity using xenogeneic cells; however, it appears that human ASCs are sufficiently well tolerated in this proofof-concept model. This immunoprivileged status is probably due to a lack of MHC molecules, as has been shown in other recent studies [13-15].

If our results are confirmed there would be translational potential, in humans, endoscopic injection could be a simple, well-tolerated route of delivering cells directly into the damaged area, through a technique routinely used in patients with IBD for both diagnostic and therapeutic purposes [66], including pharmacological local injection treatment [67-69]. Cell-based therapies are currently being tested in different phases in humans, reporting efficacy of intravenous infusion with various doses and regimens of BM-MSCs, both autologous and allogeneic [32-34]. Other studies have focused on local treatment for fistulizing disease, showing improved healing with BMMSCs [70] or ASCs [29-31, 35, 70].

\section{Conclusions}

In conclusion, our study provides evidence that endoscopy is a safe and reliable method to administer cell therapy into the colon and to follow up colitis murine models. ASC treatment ameliorates the course of TNBS colitis and prevents stenosis development.

\section{Additional files}

Additional file 1: Figure S1. Endoscopic score correlation with weight change at day 1 (A) and 11 (B). (PPTX $2289 \mathrm{~kb}$ )

Additional file 2: Figure S2. The macroscopic damage score correlates with weight change (A) and with endoscopic score (B). (PPTX 2254 kb)

Additional file 3: Figure S3. The endoscopic score correlation with the colon length 2. (PPTX $37 \mathrm{~kb}$ )

\section{Abbreviations}

APCs: Antigen-presenting cells; ASCs: Adipose-derived mesenchymal stem cells; BM-MSCs: Bone marrow mesenchymal stem cells; CD: Crohn's disease; FBS: Fetal bovine serum; IBD: Inflammatory bowel disease; IL: Interleukin; INF: Interferon; MHC: Major histocompatibility complex; MLN: Mesenteric lymph nodes; MSCs: Mesenchymal stem cells; PBS: Phosphate-buffered saline; RT: Room temperature; TBST: Tris-buffered saline with Tween 20;

TNBS: Trinitrobenzenesulfonic acid; UC: Ulcerative colitis

\section{Acknowledgements}

The authors would like to thank Jesus Diez for his statistical support, Dr. Carlota Largo Aramburu for her veterinary support and the Hospital Universitario La Paz Inflamatory Bowel Disease Unit and Cell Therapy Laborathory members for their help and support for the study.

\section{Funding}

This work was partially supported by a grant of the Instituto de Salud Carlos III to FdM (PI10/0317).

\section{Availability of data and materials}

All data generated or analyzed during this study are included in this published article (and its supplementary information file).

\section{Authors' contributions}

EM, MDM, FdM and EL designed the study, analyzed and interpreted the data. EM wrote the draft, MDM, FdM, OR, DB, FdM and EL reviewed the draft and made important contributions to the final manuscript: All authors 
collected data and reviewed contributed and approved the final version of the manuscript.

\section{Ethics approval and consent to participate}

All the animal experiments were performed following approval from the Animal Experimental and Welfare Ethics Committee of La Paz University Hospital (CEBA 24-2010), and in accordance with the guidelines of the directive 2010/63/EU from the European Parliament and of the Council on the protection of animals used for scientific purposes and the corresponding Spanish regulations (RD53/2013.

\section{Consent for publication}

Not applicable.

\section{Competing interests}

PM, RM, OR and EL are full-time employees of Tigenix SAU; EM received consultancy fees from Cellerix SAU (now Tigenix). DB is a full-time employee of Grifols. All the other authors have no conflicts of interest to disclose.

\section{Publisher's Note}

Springer Nature remains neutral with regard to jurisdictional claims in published maps and institutional affiliations.

\section{Author details}

${ }^{1}$ Gastroenterology Department, La Paz University Hospital, Paseo de la Castellana 261 4th floor, 28046 Madrid, Spain. ${ }^{2}$ Cell Therapy Laboratory, La Paz Hospital Institute for Health Research, Madrid, Spain. ${ }^{3}$ Tigenix SAU, Tres Cantos, Madrid, Spain. ${ }^{4}$ Pathology Department, La Paz University Hospital, Madrid, Spain. ${ }^{5}$ Grifols SA, Sant Cugat del Vallés, Barcelona, Spain.

\section{Received: 1 November 2017 Revised: 9 March 2018} Accepted: 13 March 2018 Published online: 10 April 2018

\section{References}

1. D'Haens G, Sartor RB, Silverberg MS, Petersson J. Rutgeerts P Future directions in inflammatory bowel disease management. J Crohns Colitis. 2014;8(8):726-34. https://doi.org/10.1016/j.crohns.2014.02.025.

2. Katz AJ, Tholpady A, Tholpady SS, Shang H. Ogle RC cell surface and transcriptional characterization of human adipose-derived adherent stromal (hADAS) cells. Stem Cells. 2005;23(3):412-23. https://doi.org/10.1634/stemcells. 2004-0021

3. Chamberlain G, Fox J, Ashton B, Middleton J. Concise review: mesenchymal stem cells: their phenotype, differentiation capacity, immunological features, and potential for homing. Stem Cells. 2007;25(11):2739-49. https://doi.org/ 10.1634/stemcells.2007-0197.

4. English K. Mechanisms of mesenchymal stromal cell immunomodulation. Immunol Cell Biol. 2013;91(1):19-26. https://doi.org/10.1038/icb.2012.56

5. Aggarwal S, Pittenger MF. Human mesenchymal stem cells modulate allogeneic immune cell responses. Blood. 2005;105(4):1815-22. https://doi.org/10.1182/blood-2004-04-1559.

6. Singer NG, Caplan Al. Mesenchymal stem cells: mechanisms of inflammation. Annu Rev Pathol. 2011;6:457-78. https://doi.org/10.1146/ annurev-pathol-011110-130230

7. Liotta F, Angeli R, Cosmi L, Fili L, Manuelli C, Frosali F, et al. Toll-like receptors 3 and 4 are expressed by human bone marrow-derived mesenchymal stem cells and can inhibit their T-cell modulatory activity by impairing Notch signaling. Stem Cells. 2008;26(1):279-89. https://doi.org/10. 1634/stemcells.2007-0454.

8. Doorn J, Moll G, Le Blanc K, van Blitterswijk C, de Boer J. Therapeutic applications of mesenchymal stromal cells: paracrine effects and potential improvements. Tissue Eng Part B Rev. 2012;18(2):101-15. https://doi.org/10.1089/ten.TEB.2011.0488

9. Akiyama K, Chen C, Wang D, Xu X, Qu C, Yamaza T, et al. Mesenchymalstem-cell-induced immunoregulation involves FAS-ligand-/FAS-mediated T cell apoptosis. Cell Stem Cell. 2012;10(5):544-55. https://doi.org/10.1016/j. stem.2012.03.007.

10. Le Blanc K, Tammik C, Rosendahl K, Zetterberg E, Ringdén O. HLA expression and immunologic properties of differentiated and undifferentiated mesenchymal stem cells. Exp Hematol. 2003;31(10):890-6.
11. Griffin MD, Ritter T, Mahon BP. Immunological aspects of allogeneic mesenchymal stem cell therapies. Hum Gene Ther. 2010;21(12):1641-55. https://doi.org/10.1089/hum.2010.156.

12. Lopez-Santalla M, Mancheño-Corvo P, Escolano A, Menta R, DelaRosa O, Abad JL, Büscher D, Redondo JM, Bueren JA, Dalemans W, Lombardo E, Garin MI. Biodistribution and efficacy of human adipose-derived mesenchymal stem cells following intranodal administration in experimental colitis. Front Immunol. 2017;8:638. https://doi.org/10.3389/fimmu.2017.00638.

13. Gonzalez Rey E, Anderson P, González MA, Rico L, Büscher D, Delgado M. Human adult stem cells derived from adipose tissue protect against experimental colitis and sepsis. Gut. 2009;58(7):929-39. https://doi.org/ 10.1136/gut.2008.168534.

14. González MA, Gonzalez-Rey E, Rico L, Büscher D, Delgado M. Adiposederived mesenchymal stem cells alleviate experimental colitis by inhibiting inflammatory and autoimmune responses. Gastroenterology. 2009;136(3): 978-89. https://doi.org/10.1053/j.gastro.2008.11.041.

15. Anderson P, Souza-Moreira L, Morell M, Caro M, O'Valle F, Gonzalez-Rey E, Delgado M. Adipose-derived mesenchymal stromal cells induce immunomodulatory macrophages which protect from experimental colitis and sepsis. Gut. 2013;62:1131-41. https://doi.org/10.1136/gutjnl-2012-302152.

16. Chen Q-Q, Yan L, Wang C-Z, Wang W-H, Shi H, Su B-B, Zeng Q-H, Du H-T, Wan J. Mesenchymal stem cells alleviate TNBS-induced colitis by modulating inflammatory and autoimmune responses. World J Gastroenterol. 2013;19:4702-17. https://doi.org/10.3748/wjg.v19.i29.4702.

17. Chao K, Zhang S, Qiu Y, Chen X, Zhang X, Cai C, Peng Y, Mao R, PevsnerFischer M, Ben-Horin S, Elinav E, Zeng Z, Chen B, He Y, Xiang AP, Chen M. Human umbilical cord-derived mesenchymal stem cells protect against experimental colitis via CD5(+) B regulatory cells. Stem Cell Res Ther. 2016;7: 109. https://doi.org/10.1186/s13287-016-0376-2.

18. Song J-Y, Kang HJ, Hong JS, Kim CJ, Shim J-Y, Lee CW, Choi J. Umbilical cord-derived mesenchymal stem cell extracts reduce colitis in mice by repolarizing intestinal macrophages. Sci Rep. 2017;7:9412. https://doi.org/10. 1038/s41598-017-09827-5.

19. Castelo-Branco MTL, Soares IDP, Lopes DV, Buongusto F, Martinusso CA, do Rosario A, et al. Intraperitoneal but not intravenous cryopreserved mesenchymal stromal cells home to the inflamed colon and ameliorate experimental colitis. PLoS One. 2012;7(3):e33360. https://doi.org/10.1371/journal.pone.0033360.g007.

20. Gonçalves FDC, Schneider N, Pinto FO, Meyer FS, Visioli F, Pfaffenseller B, Lopez PLDC, Passos EP, Cirne-Lima EO, Meurer L, Paz AH. Intravenous vs intraperitoneal mesenchymal stem cells administration: what is the best route for treating experimental colitis? World J Gastroenterol. 2014;20: 18228-39. https://doi.org/10.3748/wjg.v20.i48.18228.

21. Duijvestein M, Wildenberg ME, Welling MM, Hennink S, Molendijk I, van Zuylen VL, Bosse T, Vos ACW, de Jonge-Muller ESM, Roelofs $H$, van der Weerd L, Verspaget HW, Fibbe WE, te Velde AA, van den Brink GR, Hommes DW. Pretreatment with interferon- $\gamma$ enhances the therapeutic activity of mesenchymal stromal cells in animal models of colitis. Stem Cells. 2011;29: 1549-58. https://doi.org/10.1002/stem.698.

22. Fan H, Zhao G, Liu L, Liu F, Gong W, Liu X, Yang L, Wang J, Hou Y. Pre-treatment with IL-1 $\beta$ enhances the efficacy of MSC transplantation in DSS-induced colitis. Cell Mol Immunol. 2012;9:473-81. https://doi.org/10.1038/cmi.2012.40.

23. Fuenzalida P, Kurte M, Fernandez-O'Ryan C, Ibanez C, Gauthier-Abeliuk M, VegaLetter AM, Gonzalez P, Irarrazabal C, Quezada N, Figueroa F, Carrion F. Toll-like receptor 3 pre-conditioning increases the therapeutic efficacy of umbilical cord mesenchymal stromal cells in a dextran sulfate sodium-induced colitis model. Cytotherapy. 2016;18:630-41. https://doi.org/10.1016/j.jcyt.2016.02.002.

24. Cheng W, Su J, Hu Y, Huang Q, Shi H, Wang L, Ren J. Interleukin-25 primed mesenchymal stem cells achieve better therapeutic effects on dextran sulfate sodium-induced colitis via inhibiting Th17 immune response and inducing T regulatory cell phenotype. Am J Transl Res. 2017;9:4149-60.

25. Yang J, Liu X-X, Fan H, Tang Q, Shou Z-X, Zuo D-M, Zou Z, Xu M, Chen Q-Y, Peng $Y$, Deng $S$-J, Liu $Y$-J. Extracellular vesicles derived from bone marrow mesenchymal stem cells protect against experimental colitis via aAttenuating colon inflammation, oxidative stress and apoptosis. PLoS One. 2015;10:e0140551. https://doi.org/10.1371/journal.pone.0140551.

26. Legaki E, Roubelakis MG, Theodoropoulos GE, Lazaris A, Kollia A, Karamanolis G, Marinos E, Gazouli M. Therapeutic potential of secreted molecules derived from human amniotic fluid mesenchymal stem/stroma cells in a mice model of colitis. Stem Cell Rev Rep. 2016:1-9. https:/doi.org/10.1007/s12015-016-9677-1.

27. Duijvestein M, Molendijk I, Roelofs H, Vos ACW, Verhaar AP, Reinders MEJ, Fibbe WE, Verspaget HW, van den Brink GR, Wildenberg ME, Hommes DW. 
Mesenchymal stromal cell function is not affected by drugs used in the treatment of inflammatory bowel disease. Cytotherapy. 2011;13:1066-73. https://doi.org/10.3109/14653249.2011.597379.

28. Mancheño-Corvo P, Franquesa M, la Rosa de O, Ramirez C, GarcíaBenzaquén L, Fernández V, Menta R, Beraza A, Dalemans W, Hoogduijn MJ, Lombardo E. Adipose mesenchymal stromal cell function is not affected by methotrexate and azathioprine. Biores Open Access. 2013;2:431-9. https:// doi.org/10.1089/biores.2013.004.

29. Garcia-Olmo D, Garcia-Arranz M, Herreros D, Pascual I, Peiro C, Rodriguez Montes JA. A Phase I clinical trial of the treatment of Crohn's fistula by adipose mesenchymal stem cell transplantation. Dis Colon rectum. 2005; 48(7):1416-23. https://doi.org/10.1007/s10350-005-0052-6.

30. Garcia-Olmo D, Herreros D, Pascual I, Pascual JA, Del-Valle E, Zorrilla J, et al. Expanded adipose-derived stem cells for the treatment of complex perianal fistula. Dis Colon Rectum. 2009;52(1):79-86. https://doi.org/10.1007/DCR. Ob013e3181973487.

31. la Portilla DF, Alba F, Garcia-Olmo D, Herrerias JM, Gonzalez FX, Galindo A Expanded allogeneic adipose-derived stem cells (eASCs) for the treatment of complex perianal fistula in Crohn's disease: results from a multicenter phase I/lla clinical trial. Int J Color Dis. 2013;28(3):313-23. https://doi.org/10. 1007/s00384-012-1581-9.

32. Duijvestein M, Vos ACW, Roelofs $H$, Wildenberg ME, Wendrich BB, Verspaget $\mathrm{HW}$, et al. Autologous bone marrow-derived mesenchymal stromal cell treatment for refractory luminal Crohn's disease: results of a phase I study. Gut. 2010;59(12):1662-9. https://doi.org/10.1136/gut.2010.215152.

33. Forbes GM, Sturm MJ, Leong RW, Sparrow MP, Segarajasingam D, Cummins $A G$, et al. A phase 2 study of allogeneic mesenchymal stromal cells for luminal Crohn's disease refractory to biologic therapy. Clin Gastroenterol Hepatol. 2014;12(1):64-71. https://doi.org/10.1016/j.cgh.2013.06.021.

34. Osiris Therapeutics. A phase III, multicenter, placebo-controlled, randomized, double-blind study to evaluate the safety and efficacy of PROCHYMAL ${ }^{\circledR}$ (ex vivo cultured adult human mesenchymal stem cells) intravenous infusion for the induction of remission in subjects experiencing treatment-refractory moderate-to-severe Crohn's disease. Clinicaltrials.Gov. Available at: http:// www.clinicaltrials.gov/ct2/show/NCT00482092. Accessed 8 June 2014.

35. Panés J, Garcia-Olmo D, Van Assche G, Colombel JF, Reinisch W, Baumgart DC, Dignass A, Nachury M, Ferrante M, Kazemi-Shirazi L, Grimaud JC, la Portilla de F, Goldin E, Richard MP, Leselbaum A, Danese S, ADMIRE CD Study Group Collaborators. Expanded allogeneic adipose-derived mesenchymal stem cells (Cx601) for complex perianal fistulas in Crohn's disease: a phase 3 randomised, double-blind controlled trial. Lancet. 2016; 388:1281-90. https://doi.org/10.1016/S0140-6736(16)31203-X.

36. Ando $Y$, Inaba M, Sakaguchi $Y$, Tsuda M, Quan GK, Omae M, et al. Subcutaneous adipose tissue-derived stem cells facilitate colonic mucosal recovery from 2,4,6-trinitrobenzene sulfonic acid (TNBS)-induced colitis in rats. Inflamm Bowel Dis. 2008;14(6):826-38. https://doi.org/10.1002/ibd.20382.

37. Lombardo E, DelaRosa O, Mancheño-Cono P, Menta R, Ramirez C. Büscher D Toll-like receptor-mediated signaling in human adipose-derived stem cells: implications for immunogenicity and immunosuppressive potential. Tissue Eng Part A. 2009;15(7):1579-89. https://doi.org/10.1089/ten.tea.2008.0340.

38. Dominici M, Le Blanc K, Mueller I, Slaper-Cortenbach I, Marini F, Krause D, et al. Minimal criteria for defining multipotent mesenchymal stromal cells. The International Society for Cellular Therapy position statement. Cytotherapy. 2006;8(4):315-7. https://doi.org/10.1080/14653240600855905.

39. Bourin P, Bunnell BA, Casteilla L, Dominici M, Katz AJ, March KL, et al. Stromal cells from the adipose tissue-derived stromal vascular fraction and culture expanded adipose tissue-derived stromal/stem cells: a joint statement of the International Federation for Adipose Therapeutics and Science (IFATS) and the International Society for Cellular Therapy (ISCT). Cytotherapy. 2013;15(6):641-8. https://doi.org/10.1016/j.jcyt.2013.02.006.

40. Morris G, Beck PL, Herridge M, Depew W. Hapten-induced model of chronic inflammation and ulceration in the rat colon. Gastroenterology. 1989;96: 795-803.

41. Neurath MF, Fuss I, Strober W. TNBS-colitis. Int Rev Immunol. 2000;19(1):51-62.

42. Vermeulen W, De Man JG, Nullens S, Pelckmans PA, De Winter BY, Moreels TG. The use of colonoscopy to follow the inflammatory time course of TNBS colitis in rats. Acta Gastroenterol Belg. 2011;74(2):304-11.

43. Becker C, Fantini MC, Wirtz S, Nikolaev A, Kiesslich R, Lehr HA, et al. In vivo imaging of colitis and colon cancer development in mice using high resolution chromoendoscopy. Gut. 2005;54(7):950-4. https://doi.org/10.1136/ gut.2004.061283
44. Ahn B, Ko K-H, Oh T-Y, Cho H, Kim W-B, Lee K-J, et al. Efficacy of use of colonoscopy in dextran sulfate sodium induced ulcerative colitis in rats: the evaluation of the effects of antioxidant by colonoscopy. Int J Color Dis. 2001;16(3):174-81. https://doi.org/10.1007/s003840000282.

45. Pacheco RG, Esposito CC, Müller LCM, Castelo-Branco MTL, Quintella LP, Chagas VLA, et al. Use of butyrate or glutamine in enema solution reduces inflammation and fibrosis in experimental diversion colitis. World J Gastroenterol. 2012;18(32):4278-87. https://doi.org/10.3748/wjg.v18.i32.4278.

46. Daperno M, D'Haens G, Van Assche G, Baert F, Bulois P, Maunoury V, et al. Development and validation of a new, simplified endoscopic activity score for Crohn's disease: the SES-CD. Gastrointest Endosc. 2004;60(4):505-12.

47. Schroeder KW, Tremaine WJ, Ilstrup DM. Coated oral 5-aminosalicylic acid therapy for mildly to moderately active ulcerative colitis. A randomized study. N Engl J Med. 1987;317(26):1625-9. https://doi.org/10.1056/ NEJM198712243172603

48. Mary JY, Modigliani R. Development and validation of an endoscopic index of the severity for Crohn's disease: a prospective multicentre study. Groupe d'Etudes Thérapeutiques des Affections Inflammatoires du Tube Digestif (GETAID). Gut. 1989;30(7):983-9.

49. Soetikno R, Kaltenbach T. Dynamic submucosal injection technique. Gastrointest Endosc Clin N Am. 2010;20(3):497-502. https://doi.org/10.1016/j. giec.2010.03.008.

50. Tanaka F, Tominaga K, Ochi M, Tanigawa T, Watanabe T, Fujiwara Y, et al. Exogenous administration of mesenchymal stem cells ameliorates dextran sulfate sodium-induced colitis via anti-inflammatory action in damaged tissue in rats. Life Sci. 2008;83(23-24):771-9. https://doi.org/10. 1016/j.lfs.2008.09.016.

51. Khalil PN, Weiler V, Nelson PJ, Khalil MN, Moosmann S, Mutschler WE, et al. Nonmyeloablative stem cell therapy enhances microcirculation and tissue regeneration in murine inflammatory bowel disease. Gastroenterology. 2007;132(3):944-54. https://doi.org/10.1053/j.gastro.2006.12.029.

52. Hayashi Y, Tsuji S, Tsujii M, Nishida T, Ishii S, lijima H, et al. Topical implantation of mesenchymal stem cells has beneficial effects on healing of experimental colitis in rats. J Pharmacol Exp Ther. 2008;326(2):523-31. https://doi.org/10.1124/jpet.108.137083.

53. Parekkadan B, Upadhyay R, Dunham J, Iwamoto $Y$, Mizoguchi E, Mizoguchi A, et al. Bone marrow stromal cell transplants prevent experimental enterocolitis and require host CD11b+ splenocytes. Gastroenterology. 2011; 140(3):966-75. e4. https://doi.org/10.1053/j.gastro.2010.10.013.

54. Manieri NA, Mack MR, Himmelrich MD, Worthley DL, Hanson EM, Eckmann $L$, et al. Mucosally transplanted mesenchymal stem cells stimulate intestinal healing by promoting angiogenesis. J Clin Invest. 2015 Sep;125(9):3606-18.

55. Kidd S, Spaeth E, Dembinski JL, Dietrich M, Watson K, Klopp A, et al. Direct Evidence of mesenchymal stem cell tropism for tumor and wounding microenvironments using in vivo bioluminescent imaging. Stem Cells. 2009; 27(10):2614-23. https://doi.org/10.1002/stem.187.

56. Schrepfer S, Deuse T, Reichenspurner H, Fischbein MP, Robbins RC, Pelletier MP. Stem cell transplantation: the lung barrier. Transplant Proc. 2007;39(2): 573-6. https://doi.org/10.1016/j.transproceed.2006.12.019.

57. Wirtz S, Neufert C, Weigmann B, Neurath MF. Chemically induced mouse models of intestinal inflammation. Nat Protoc. 2007;2(3):541-6. https://doi. org/10.1038/nprot.2007.41.

58. Haughn C, Uchal M, Raftopoulos Y, Rossi S, Santucci T, Torpey M, et al. Development of a total colonoscopy rat model with endoscopic submucosal injection of the cecal wall. Surg Endosc. 2005;20(2):270-3. https://doi.org/10.1007/s00464-005-0088-7.

59. Karas JR, Essani R, Haughn C, Uchal M, Bishawi MM, Bergamaschi R. Colonoscopic injection for murine solid cecal cancer model. Surg Endosc. 2011;25(9):2956-9. https://doi.org/10.1007/s00464-011-1651-z.

60. Neurath MF, Wittkopf N, Wlodarski A, Waldner M, Neufert C, Wirtz S, et al. Assessment of tumor development and wound healing using endoscopic techniques in mice. Gastroenterology. 2010;139(6):1837-43. e1. https://doi. org/10.1053/j.gastro.2010.10.007.

61. Narisawa T, Wong CQ, Weisburger JH. Evaluation of endoscopic examination of colon tumors in rats. Am J Dig Dis. 1975;20(10):928-34.

62. Hull CC, Stellato TA, Ament AA, Gordon N, Galloway P. Endoscopic and radiographic evaluation of the murine colon. Cancer. 1990;66(12):2528-32.

63. Hamilton SR, Zhang SZ, O'Ceallaigh D, McAvinchey D. Growth characteristics of autochthonous experimental colonic tumors as assessed by serial colonoscopic measurement in rats. Gastroenterology. 1986;91(6): 1511-20. 
64. Iwai A, Iwashita E. Changes in colonic inflammation induced by dextran sulfate sodium (DSS) during short- and long-term administration of rebamipide. Dig Dis Sci. 1998;43(9 Suppl):143S-7S.

65. Eggenhofer E, Luk F, Dahlke MH, Hoogduijn MJ. The life and fate of mesenchymal stem cells. Front Immunol. 2014;5:148. https://doi.org/10. 3389/fimmu.2014.00148.

66. Annese V, Daperno M, Rutter MD, Amiot A, Bossuyt P, East J, et al. European evidence based consensus for endoscopy in inflammatory bowel disease. J Crohns Colitis. 2013;7(12):982-1018. https://doi.org/10.1016/j.crohns.2013.09.016.

67. Swaminath A, Lichtiger S. Dilation of colonic strictures by intralesional injection of infliximab in patients with Crohn's colitis. Inflamm Bowel Dis. 2008;14(2):213-6. https://doi.org/10.1002/ibd.20318.

68. Poggioli G, Laureti S, Pierangeli F, Rizzello F, Ugolini F, Gionchetti P, et al. Local injection of infliximab for the treatment of perianal Crohn's disease. Dis Colon Rectum. 2005:48(4):768-74. https://doi.org/10.1007/s10350-004-0832-4

69. Biancone L, Cretella M, Tosti C, Palmieri G, Petruzziello C, Geremia A, et al. Local injection of infliximab in the postoperative recurrence of Crohn's disease. Gastrointest Endosc. 2006;63(3):486-92. https://doi.org/10.1016/j.gie. 2005.08.047

70. Ciccocioppo R, Bernardo ME, Sgarella A, Maccario R, Avanzini MA, Ubezio C, et al. Autologous bone marrow-derived mesenchymal stromal cells in the treatment of fistulising Crohn's disease. Gut. 2011;60(6):788-98. https://doi. org/10.1136/gut.2010.214841

\section{Submit your next manuscript to BioMed Central and we will help you at every step:}

- We accept pre-submission inquiries

- Our selector tool helps you to find the most relevant journal

- We provide round the clock customer support

- Convenient online submission

- Thorough peer review

- Inclusion in PubMed and all major indexing services

- Maximum visibility for your research

Submit your manuscript at www.biomedcentral.com/submit

C) Biomed Central 